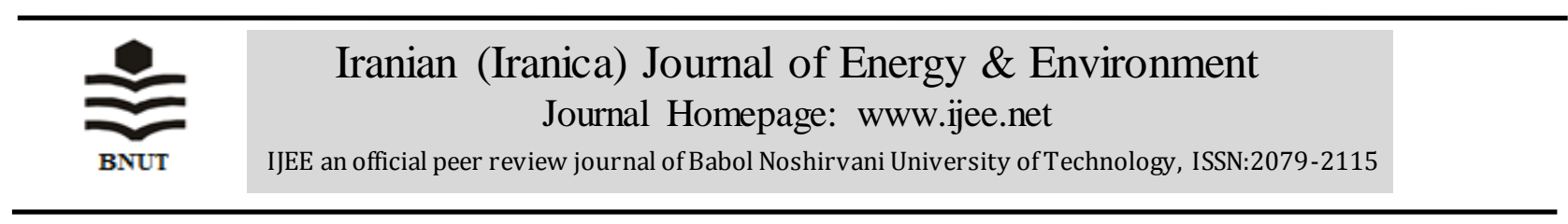

\title{
Vulnerability of Vegetable Crops to the Impact of Climatic variability and the Management Techniques in the Guinea Savanna Region of Nigeria
}

\author{
A. M. Tunde*
}

Department of Geography \& amp; Environmental Management, University of Ilorin, Nigeria

\section{PAPER INFO}

\section{Paperhistory:}

Received 31 March 2019

Accepted in revised form 24 June 2019

\section{Keywords:}

Agriculture

Climate Variables

Kwara State Agricultural Development

Rainfall

Variability

Vegetable Crops

\section{$A B S T R A B C T$}

Climatic parameters are part of the main determinants of agricultural production in many developing countries including Nigeria. This study analyzes the vulnerability of vegetable crops to the impact of rainfall and temperature variability and the management techniques in Kwara State agro-ecological region of Nigeria. Data on rainfall, temperature and vegetables (tomato, pepper, okra, amaranthus and garden egg) were collected for a period of twenty-five (25) years from the four agricultural zones of Kwara State. These were subjected to descriptive, correlation and regression analyses. The result revealed that climatic variables examined fluctuate but there has been constant increase in temperature over the years and year 2001 recorded the highest $\left(40.06^{\circ} \mathrm{C}\right)$. Vegetable crop yield also fluctuates. Correlation analysis revealed that tomato correlates positively with rainfall, maximum and minimum temperature. Okra and pepper correlate positively with rainfall and maximum temperature and inverse correlation with minimum temperature. Amaranthus has an inverse correlation with rainfall and maximum temperature but correlates positively with minimum temperature although very low. Garden egg correlates with rainfall and inversely correlates with maximum and minimum temperature. Hence, vegetable crops examined are vulnerable to the impact of climatic variables but not too strong as there are other factors such as the nature of soil, specie of seedlings, chemicals among others that contributed to vegetable crop yield. Management techniques suggested to improve the productivity of vegetable crops in Kwara State include the use of modern agricultural techniques such as development of irrigation and water harvesting technologies.

doi: $10.5829 /$ ijee.2019.10.02.12

\section{INTRODUCTION}

A lot have been said and written about climate variability and agricultural production in many developing countries including Nigeria. United Nations Environment Program UNEP [1] observed that economic and agricultural sectors in these countries are likely to face difficulties related to climate change. For instance, Cho [2] confirmed that if greenhouse gas emissions continue on their current trajectory, yields of vegetable and legume could fall by 35 percent by 2100 due to water scarcity, increased salinity and high rate of ozone depletion. Nalik et al. [3] pointed out that climate change influences vegetable production globally but its nature and impact vary, depending on the degree of climate change, geographical region, and crop production system.

Abewoy [4] reported that changes in weather elements experienced from 1960s to date have impacted agriculture and human activities in different ecological zones of Nigeria. A study conducted in Bangledesh revealed that a rise in temperature of $1-2^{\circ} \mathrm{C}$ in combination with lower radiation

* Corresponding Author Email: afolabi@unilorin.edu.ng (Afolabi Monisola Tunde) causes sterility in rice spikelet [5]. Furthermore, in Nigeria, studies have shown that variations in climatic factors mostly rainfall and temperature correlate with food crop production and yield [6-8]. Hence, food crop consists of different classes including vegetables.

A vegetable can be defined as an edible plant or part of a plant. Vegetable crops can be classified as fruit vegetables such as watermelon, tomato, cucumber, peas; root and tuber/root vegetables such as carrot, irish potato, sweet potato; green leafy vegetables such as amaranthus, celery, cabbage, curry leaf and bulb vegetables such as onion and garlic [4]. Vegetables contribute immensely to human calorific intake and nutrition worldwide. Consumption of vegetables makes vitamins, minerals and energy available to human body generally.

Tomato is the most important vegetable crop worldwide and is grown over four million hectares of land area [9]. In Nigeria, most households rely very much on vegetables consumption for diverse reasons. For instance, it has been reported by Hang [10] that vegetables possess both curative and preventive measures against diseases, and reduce repetition of nutrition. Similarly, Sirmin et al. [11] pointed out that high intake of fruits and vegetables reduces 
cardiovascular diseases. Furthermore, vegetables provide better balanced diet, vitamins and minerals. According to Ogunlesi et al. [12], fluted pumpkin is about 129.39 $\mathrm{mg} / 100 \mathrm{~g}$ rich in vitamin $\mathrm{C}$.

Despite these benefits, report has however revealed that there has been an undulating pattern in the trend of vegetable production in Nigeria, for instance about 4924.9 thousand tonnes were produced in 2005, while 2487.7 thousand tonnes were produced in 2006 [13]. Bhardwaj [9] opined that vegetables are generally sensitive to environmental extremes, and thus high temperature is a major cause of low yields. He went further to reiterate that increasing temperature, reduced irrigation water availability; flooding and salinity are the major limiting factors in sustaining and increasing vegetable productivity. In the same vein, it was discovered that environmental factors such as temperature and rainfall have negative effects on tomato production. Nalik et al. [2] observed that carbon-dioxide is a major greenhouse gas that influences growth and development as well as incidence of insect pests and diseases of vegetable crops. Adeniyi [14] reported that some selected climatic elements over a period of ten (10) years have weak impact on okra, sweet potato, pepper, and amaranthus yield in Ilorin, Kwara State.

The question therefore is that, what impact do rainfall and temperature have on agricultural production particularly vegetables in the study area? Does the undulating pattern of vegetable production in Nigeria also exist in Kwara State? Will there be any significant difference between past studies carried out for a period of ten (10) years in the State and the present study? It is against this background of study that this study analyzes the vulnerability of vegetable crops to the impact of rainfall and temperature variability and the management techniques in Kwara State a Guinea savanna agro-ecological region of Nigeria.

\section{IMPACT OF CLIMATIC VARIABLES ON VEGETABLE CROPS}

Agricultural production generally in Nigeria is rain-fed as smallholder farmers rely heavily on the onset of rain for cultivation. Heavy rain and flooding cause vegetable shortage, Jayapiratha et al. [15] carried out a research on the performance evaluation of okro (Hibiscus esculentus) under drip irrigation system and discovered that when the availability of moisture and moisture retention capacity increases, the growth of the okra also increases. Chili pepper (Capsicium annuum $L$ ) thrives well at annual rainfall amount of between $600 \mathrm{~mm}$ and $1250 \mathrm{~mm}$ [16]. Okra does best in warm moist soils and annual rainfall amount of up to 1000 $\mathrm{mm}$ [17]. The water requirement of outdoor grown tomatoes varies between $4000-6000 \mathrm{~m}^{3} / \mathrm{ha}$ [18].

Variations in the daily mean maximum and minimum temperature affect vegetable production because its physiological, bio-chemical and metabolic activities are temperature dependent. Temperature can affect vegetable crops in so many ways: timing and reliability of plant growth, flowering, fruit growth, and ripening [19]. Kondinya et al. [20] reported that drought and salinity are the two important consequences of increase in temperature worsening vegetable cultivation. Similarly, Abewoy [4] pointed out that drought and salinity as a result of increase in temperature influence the occurrences of pest and disease host-pathogen interactions, there by becoming major setback to vegetable cultivation. Rise in temperature during winter usually results in increasing viral diseases of crops like potato and sugar-beet [21].The optimum temperature range for fruit set is $18^{\circ}$ to $24^{\circ} \mathrm{C}$ [22].

According to Ernest [23], high temperature will limit yields in many vegetables and fruits because it increased developmental disorders in fruiting vegetables. For example it has been reported by De Koning [24] that tomato (Solanum lycopersicum) can compensate for variation in temperature within a certain range and period, also thrives well in temperature $10^{\circ} \mathrm{C}$ to $30^{\circ} \mathrm{C}$ with optimum range of temperature $21-24^{\circ} \mathrm{C}$. Mean daily temperatures of $27^{\circ} \mathrm{C}$ and $29^{\circ} \mathrm{C}$ can have adverse effects on tomato fruit set and yield [25]. Pepper thrives well with temperature of between 18 to $27^{\circ} \mathrm{C}$ during the day and 15 to $18^{\circ} \mathrm{C}$ at night. Fertilization in pepper is sensitive to high temperature [26]. Amaranthus (Amaranthus hybridus) requires soil temperature of between $18^{\circ} \mathrm{C}$ and $25^{\circ} \mathrm{C}$ to germinate and air temperature of $25^{\circ} \mathrm{C}$ for optimum growth [27]. Okra is a hot weather crop and the optimum soil temperature for its growth is 24 to $32^{\circ} \mathrm{C}$, while the minimum soil temperature is $18{ }^{\circ} \mathrm{C}$ [28]. According to MOFA [29] garden eggs (Solanum spp) prefer day warm temperatures of $\left(32^{\circ} \mathrm{C}\right)$ and night $\left(21^{\circ} \mathrm{C}\right)$ for optimum growth and development.

\section{THE STUDY AREA}

The study area for this research is Kwara State (Figure 1.) which lies at the Guinea savanna region of Nigeria. The State is located between latitudes $8^{\circ}$ and $10^{\circ} 04^{1} \mathrm{~N}$ and longitudes $2^{\circ} 45^{1} \mathrm{E}$ and $6^{\circ} 12^{1} \mathrm{E}$. It occupies an area of $36,825 \mathrm{~km}^{2}$ and consists of sixteen Local Government Areas. The State borders Niger Sate to the North, Kogi and Ekiti States to the East, Osun and Oyo States in the South and the Republic of Benin in the West. Kwara State has tropical distinct dry and rainy season with a rainy season of about nine months between March and October or sometimes

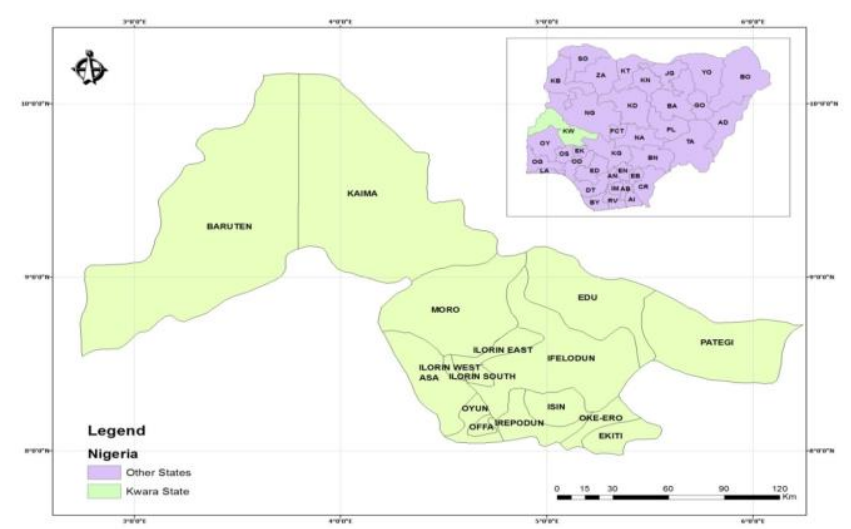

Figure 1. Kwara State showing the sixteen Local Government Areas

Source: Kwara State Ministry of Lands, 2017 
early November with a mean annual rainfall of 1,000 to $1,500 \mathrm{~mm}$. Also, the dry season is about four months from November to February and sometimes times it may extend to early March. The temperature is usually higher during the dry season than rainy season with a mean maximum temperature of between $33^{\circ} \mathrm{C}$ and $36^{\circ} \mathrm{Cwhile}$ the mean minimum temperature ranges between $19^{\circ}$ and $24^{\circ} \mathrm{C}$ for a greater part of the year (November - March). Furthermore, the absolute minimum and maximum temperature during this period is between $15^{\circ}-20^{\circ} \mathrm{C}$ and $35^{\circ} \mathrm{C}$ respectively. Some of the rivers of the State include rivers Moro, Asa, Niger, Weru, Adere and Oshin. The State is dominated by the derived guinea savannah grasslands vegetation at the northern part while some parts of the southern part falls within the rainforest agro-ecological zone. This is well suited for the cultivation of a wide variety of crops such as rice, groundnut, maize, cassava, yams, sorghum, fruits, and vegetables, among others.

The type of soil found in the State is ferruginous tropical soils which are reddish in colour and have appreciable reserve of weatherable minerals. Also, the presence of alluvial and hydromorphic soils on the banks of River Niger provided strong potentials for agricultural activities. Generally, the soils in Kwara State consist of adequate potassium, calcium, magnesium and phosphorus that can be tapped by the crops grown on them. The high potentials for agricultural production and because farming is the predominant occupation of the residents justify the reason for the choice of the State for the study.

\section{MATERIALS AND METHODS}

Kwara State Agricultural Development Project (KWADP) divided Kwara State into four (4) agricultural zones. Data on rainfall, temperature and vegetables (tomato, pepper, okra, amaranthus and garden egg) used for the study were obtained from these four agricultural zones for a period of twenty-five (25) years (See Tables 1 and 2). Zone $A$ is derived savanna area (Baruten and Kaiama), Zone B is the flood plain area (Patigi and Edu). Zone $\mathrm{C}$ is the guinea savannah area (Asa, Moro, Ilorin West, Ilorin East and Ilorin South). Zone D is the rainforest area (Irepodun, Oyun, Offa, Isin, Ekiti, Ifelodun and Oke-Ero).

TABLE 1. Climatic Data (1992-2017)

\begin{tabular}{cccc}
\hline Year & Rainfall $(\mathbf{m m})$ & Temp. Max $\left({ }^{\mathbf{O}} \mathbf{C}\right)$ & Temp. $\operatorname{Min}\left({ }^{\mathbf{O}} \mathbf{C}\right)$ \\
\hline 1992 & 108.50 & 34.00 & 25.00 \\
1993 & 1138.12 & 33.60 & 22.40 \\
1994 & 1085.02 & 34.05 & 21.75 \\
1995 & 1211.78 & 33.44 & 24.58 \\
1996 & 1700.04 & 32.70 & 26.20 \\
1997 & 1704.18 & 32.86 & 24.45 \\
1998 & 1104.50 & 35.61 & 21.30 \\
1999 & 1292.30 & 34.82 & 21.89 \\
2000 & 946.70 & 37.93 & 22.08 \\
2001 & 907.60 & 40.06 & 19.79
\end{tabular}

$\begin{array}{lccc}2002 & 1028.50 & 36.44 & 20.30 \\ 2003 & 811.75 & 31.17 & 17.50 \\ 2004 & 1597.40 & 33.33 & 20.15 \\ 2005 & 1144.50 & 35.90 & 23.90 \\ 2006 & 1236.99 & 36.47 & 22.79 \\ 2007 & 1481.63 & 37.08 & 22.50 \\ 2008 & 1381.90 & 36.00 & 22.00 \\ 2009 & 1526.57 & 38.00 & 23.40 \\ 2010 & 1165.70 & 36.00 & 23.30 \\ 2011 & 1252.80 & 36.00 & 23.00 \\ 2012 & 1617.80 & 32.40 & 23.70 \\ 2013 & 900.00 & 35.50 & 22.80 \\ 2014 & 1016.00 & 37.70 & 21.40 \\ 2015 & 806.60 & 37.30 & 22.50 \\ 2016 & 1747.20 & 35.80 & 21.03 \\ 2017 & 1504.86 & 39.80 & 21.80\end{array}$

Source: Kwara State Agricultural Development Project (KWADP), 2018

TABLE 2. Vegetable (Yield) Data ('000) (1992-2017)

\begin{tabular}{lccccc}
\hline Year & Tomato & Okra & Pepper & Amaranthus Garden Fgg \\
\hline 1992 & 1.12 & 0.60 & 1.62 & 5.55 & 3.44 \\
1993 & 2.67 & 2.02 & 2.09 & 5.41 & 3.45 \\
1994 & 1.94 & 1.38 & 1.44 & 5.27 & 3.46 \\
1995 & 1.22 & 1.91 & 1.42 & 5.13 & 3.47 \\
1996 & 3.50 & 2.45 & 2.55 & 4.99 & 3.49 \\
1997 & 3.00 & 2.39 & 1.92 & 6.05 & 6.03 \\
1998 & 1.53 & 1.83 & 3.47 & 4.20 & 6.04 \\
1999 & 6.25 & 4.17 & 3.00 & 4.92 & 6.82 \\
2000 & 3.01 & 3.10 & 5.55 & 1.90 & 4.32 \\
2001 & 3.80 & 3.50 & 2.75 & 5.33 & 4.71 \\
2002 & 3.21 & 3.49 & 2.91 & 4.25 & 3.64 \\
2003 & 1.16 & 3.42 & 1.89 & 4.95 & 3.42 \\
2004 & 3.04 & 5.01 & 1.40 & 4.50 & 4.80 \\
2005 & 1.70 & 3.90 & 2.30 & 4.40 & 6.18 \\
2006 & 3.10 & 3.90 & 1.30 & 4.50 & 3.80 \\
2007 & 3.30 & 4.00 & 2.00 & 4.00 & 3.00 \\
2008 & 4.20 & 3.75 & 2.35 & 4.40 & 3.40 \\
2009 & 5.59 & 4.14 & 4.31 & 4.60 & 3.00 \\
2010 & 6.12 & 3.53 & 3.39 & 4.72 & 3.25 \\
2011 & 5.41 & 4.45 & 4.35 & 4.01 & 3.24 \\
2012 & 5.37 & 4.18 & 4.06 & 4.36 & 3.23 \\
2013 & 6.23 & 4.49 & 4.48 & 6.10 & 3.40 \\
2014 & 6.14 & 5.96 & 4.81 & 6.28 & 3.40 \\
2015 & 5.85 & 4.78 & 4.65 & 6.19 & 3.35 \\
2016 & 5.80 & 4.70 & 4.34 & 5.46 & 3.33 \\
2017 & 6.18 & 5.01 & 4.62 & 5.81 & 3.50 \\
\hline Source: Kwara State AgriculturalDevelopment Project (KWADP), \\
\end{tabular}


Tables, trend, correlation and multiple regression analyses were used to analyze the collected data. These will show the pattern of rainfall, temperature and vegetables over the study years. It will further reveal the strength of relationships between rainfall, temperature and selected vegetables over the period under study for Kwara State, Nigeria.

\section{RESULTS}

\section{Pattern of rainfall}

Rainfall in the years under study shows an undulating pattern with the lowest rainfall in the year $1992(108.0 \mathrm{~mm})$ after that year, it rises up again until years 2000 and 2001 which have $946.70 \mathrm{~mm}$ and $906.60 \mathrm{~mm}$, respectively (Figure 2).

Year 2002 experienced an upward trend again until year 2003 that has $811.75 \mathrm{~mm}$. After this year; there was an upward trend in the rainfall till year 2017 except for years 2013 and 2015 with $800.00 \mathrm{~mm}$ and $906.00 \mathrm{~mm}$ respectively. The highest rainfall was in the year 2016 with $1747.16 \mathrm{~mm}$ rainfall.

\section{Pattern of temperature}

There is no significant difference in the degree of maximum temperature during the period of study. It was a regular trend except for year 2001 where maximum temperature was a bit higher $\left(40.06^{\circ} \mathrm{C}\right)$ than the subsequent years. The lowest maximum temperature was recorded in the year 2003 with $31.17^{\circ} \mathrm{C}$. With respect to minimum temperature, it was a regular trend except for the years 1996 which has highest $26.20^{\circ} \mathrm{C}$ and 2003 which was lowest $\left(17.50^{\circ} \mathrm{C}\right)$, respectively (Figure 3).

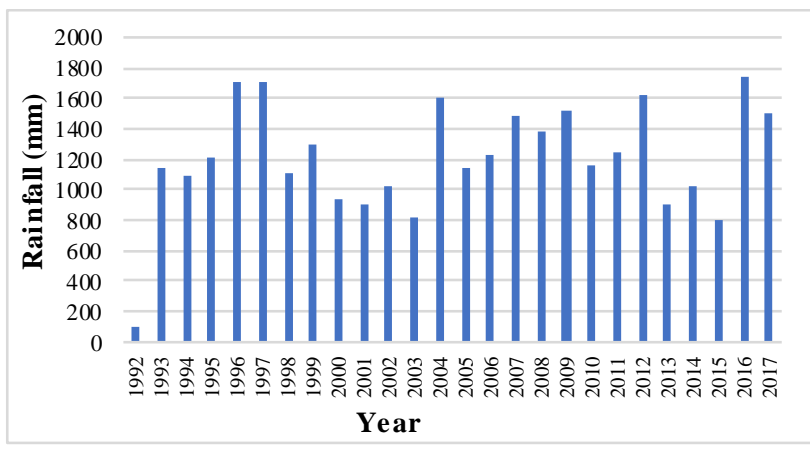

Figure 2. Rainfall Pattern of the study area Source: Author's Fieldwork/computer output, 2018

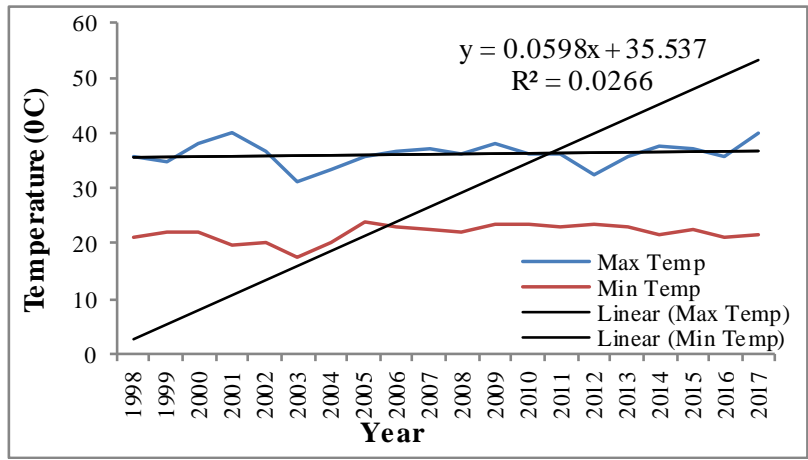

Figure 3. Trend pattern of Maximum and Minimum Temperature

Source: Author's Fieldwork/Computer output, 2018

\section{Pattern of vegetable crops yield}

Vegetable yield pattern (figure 4) reveals that vegetable production is influenced by variability in the climatic parameters to some extent. This is to be expected since vegetable production in this environment is more of rain fed rather than irrigated conditions.

For instance, tomato fluctuates in its yield with lowest value of 1.12 in the year 1992 and highest value of 6.25 in 1999. Okra has lowest yield value of 0.60 in 1992 and highest value of 5.96 in the year 2014

Furthermore, pepper's lowest yield value in the study area was in the year 2006 (1.30) and highest value of 4.81 in the year 2014. Amaranthus lowest yield value was in the year 2000 (1.90) and highest yield value of 6.28 in the year 2014. This shows a significant variation. Garden egg has lowest value of 3.00 in the years 2007 and 2009 and highest value of 6.82 in the year 1999.

\section{DISCUSSION}

Relationship between climate variables and crop yield

Table 3 reveals the relationship between rainfall, temperature (maximum and minimum) and vegetables. From the table, rainfall has positive but weak correlation with tomato (0.315), okra (0.341), pepper (0.038) and garden egg (0.071) and negative correlation with amaranthus (-0.090). The implication of this is that with relatively increase in rainfall amount, more tomato, okra, pepper and garden egg would be harvested but less amount of amaranthus will be harvested.

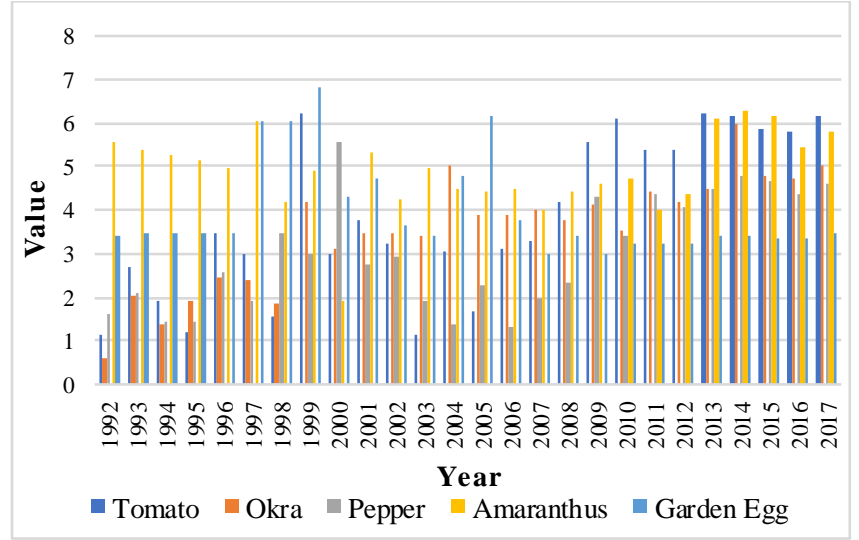

Figure 4. Pattern of Vegetable Yield

Source: Author's Fieldwork/computer output, 2018

TABLE 3. Relationship between Rainfall, Temperature and Vegetables

\begin{tabular}{lccc}
\hline Vegetables & Rainfall (mm) & $\begin{array}{c}\text { Max. Temp } \\
(\mathbf{O} \mathbf{C})\end{array}$ & $\begin{array}{c}\text { Min. Temp } \\
(\mathbf{O} \mathbf{C})\end{array}$ \\
\hline Tomato & 0.315 & 0.440 & 0.015 \\
Okra & 0.341 & 0.433 & -0.327 \\
Pepper & 0.038 & 0.525 & -0.050 \\
Amaranthus & -0.090 & -0.078 & 0.064 \\
Garden Egg & 0.071 & -0.070 & -0.044 \\
\hline
\end{tabular}

Source: Author's computation, 2018

*Correlation is significant at the 0.05 level ( 2 tailed) 
This result is not in agreement with findings of Adeniyi [14] on impact of climatic variables on vegetable crops in Ilorin, Kwara State.

Maximum temperature correlates positive but weakly with tomato (0.440), okra (0.433) and strong positively with pepper (0.525). It correlates negatively with amaranthus ($0.078)$ and garden egg (-0.070). For the minimum temperature, it correlates positively but very weak with tomato (0.015) and amaranthus (0.064) but negatively with okra (-0.327), pepper $(-0.050)$ and -0.044$)$. This can be linked with the fact that all vegetable crops under study require between $10^{\circ} \mathrm{C}$ and $32^{\circ} \mathrm{C}$ to survive but lowest maximum temperature was $31.17^{\circ} \mathrm{C}$ and highest $40.06^{\circ} \mathrm{C}$ while lowest minimum temperature was $17.50^{\circ} \mathrm{C}$ and highest was $26.20^{\circ} \mathrm{C}$. This result is in consonant with Ernest [23] who opined that high temperature will limit the yield of vegetables and fruits in his study.

On the overall, tomato correlates positively with rainfall, maximum and minimum temperature. Okra and pepper correlate positively with rainfall and maximum temperature but do not correlate with minimum temperature. Amaranthus have an inverse correlation with rainfall and maximum temperature but correlates positively with minimum temperature. Garden egg correlates positively with rainfall but weak and inversely correlated with maximum and minimum temperature. This is in support of Aondoakaa [30] that there exist positive relationship between each climatic element examined and crop yield but on a very weak significance. Similarly, Awotoye and Matthew [31] also reported that vegetable production was influenced by variability/change in the amount of rainfall. Hence, vegetable crops are vulnerable to the impact of climatic variables to some extent in the study area.

\section{Impact of climatic variability on vegetables (regression analysis)}

Table 4 shows that the studied climatic variables contributed $32 \%$ to tomato yield, $42 \%$ to okro yield, $28 \%$ to pepper yield, $27 \%$ to amaranthus and $32 \%$ to garden egg. This indicates that vegetable crops under study are vulnerable to the impact of climatic variables although there are other factors contributing to the yield of vegetables in the study area. These include nature of soil, specie of seedlings, pests, herbicides, quality and planting period among others. This corroborates the earlier findings of Awotoye and Matthew [31] that some non-climatic factors do contribute significantly to crop yield.

TABLE 4. Regression Analys is for Vegetables

\begin{tabular}{lcccccc}
\hline Vegetables & R & $\mathbf{R}^{2}$ & $\begin{array}{c}\text { Standard } \\
\text { Error }\end{array}$ & $\begin{array}{c}\text { Regression } \\
\text { Coefficient }\end{array}$ & F & $\begin{array}{c}\text { P- } \\
\text { value }\end{array}$ \\
\hline Tomato & 0.566 & 0.321 & 1.6015 & 0.350 & 3.464 & 0.034 \\
Okra & 0.655 & 0.429 & 1.0241 & 0.422 & 5.507 & 0.006 \\
Pepper & 0.533 & 0.284 & 1.1664 & 0.081 & 2.906 & 0.058 \\
Amaranthus & 0.520 & 0.270 & 0.9730 & 0.148 & -0.106 & 0.030 \\
Garden Egg & 0.562 & 0.320 & 1.1618 & 0.074 & 0.099 & 0.060 \\
\hline \multicolumn{7}{l}{ Source: Author's Fieldwork/Computer output, 2018} \\
\end{tabular}

\section{Management techniques}

The management techniques involved in mitigating and coping with the adverse effects of climatic variables on vegetable production include: development of irrigation and water harvesting technologies adoptable to the hot and dry condition as a long term measure. Crop diversification, change in vegetable crop, change in planting date and planting short duration vegetables are part of management techniques that should be adopted to combat the likely increase in temperature and water stress periods during the growing seas on [32].

Conservation of soil moisture through crop management practices like mulching with crop residues and plastic should be adopted while excessive soil moisture due to heavy rain can be overcome by growing vegetable crops on raised beds [33].

Improved soil tillage practices, soil fertility improvement and mixed cropping should be adopted as another adaptation technique [34]. Grafted plants are now being used to improve resistance against abiotic stresses like low and high temperatures, drought, salinity and flooding in vegetable crops [35].

Extension agents in the State should educate farmers on improved/modern technologies and practices while research institutions and universities should develop drought-resistant and early maturing vegetable crop varieties.

Challenges of a changing climate can be overcome by farmers through the development of climate resilient vegetables such as adapted vegetable germplasm [36]. Mix cropping and drought-resistant species should be embarked upon by farmers in the study area.

Advanced technologies and development of genotypes tolerant to high temperature, moisture stress, salinity and climate proofing through conventional, non-conventional, breeding techniques are required to complement traditional methods, which are often unable to prevent yield losses due to environmental stresses [37].

Farmers on the other hand should shift their crop production activities to less flood-prone arable lands. Government and policy makers should design and implement effective drainage systems.

\section{CONCLUSIONS}

In this study, an attempt has been made to analyze the vulnerability of vegetable crops to the impact of rainfall and temperature variability and its management techniques in the Guinea savanna agro-ecological region of Nigeria. The results however revealed that rainfall and temperature fluctuate during the period under study and do have impact on vegetable yield although other non-climatic factors such as nature of soil, seedlings, farm techniques and pests and diseases among others contributed to the impact.

Hence, based on the findings of the research, it is very crucial to understand that adequate measures to adapt to the effects of climatic variability on vegetable production should be undertaken in order not to jeopardize nutritional security in Kwara State and developing countries at large. Therefore, agricultural stakeholders should adopt neces sary strategies to reduce the adverse effects of climatic variables on vegetable 
production in the study area as well as developing countries as a whole. Off-season irrigation farming should be adopted by the farmers to sustain food production in the area. This can be achieved through formulation of farming groups and cooperative societies where resources can be pulled together to mitigate and adapt to the impact of climatic variables so as to ensure sustainable food security in the State.

\section{REFERENCES}

1. UNEP 2005, Annual Evaluation Report, 2005. https://www.unenvironment.org/resources/evaluationsynthesis-reports/unep-annual-evaluation-report-2005.

2. Cho, R. 2018. Agriculture, Climate. How Climate Change will alter our Food. State of the Planet. Earth Institute, Columbia University. News from the Earth Institute.

3. Nalik, P.S., M. Singh and J.K Ranjan, 2017. Impact of Climate Change on Vegetable Production and Adaptation Measures. In Minhas, P.,Rane, J., Pasala, R (eds). Abiotic Stress Management for Resilient Agriculture. 413-428.

4. Abewoy, D. 2018. Review on Impacts of Climate Change on Vegetable Production and its Management Practices. Advances in Crop Science Technology. 6(1): 330-336.

5. Haque, M. N. M.H., AL and S.M. Masum, 2016. Climate Change impacts on Rice Production in Bangladesh. LAP LAMBERT Academic Publishing. 1-64.

6. Sawa, B.A and A.A. Adebayo, 2011. Relationship between Dry Spells and Crop Yield in Drought Prone Areas of Northern Nigeria NMets 2011 Conference Proceedings, 502-525.

7. Mohammad, H., M.O. Akhadelor and T.S Isiaka, 2011. A Comparative Assessment of the Response of Quality Protein Maize Varieties to Rainfall and Soil in the Sudan and Guinea Savannah. NMets 2011 Conference Proceedings, 444-454.

8. Asikhia, M.O and M.O Igbafen, 2012. Food Security Implication of Climate Change and Loss of Biodiversity. Book of Proceeding of the 2012 Annual Conference of Nigerian Meteorological Society held at the Department Geography and Regional Planning, University of Benin City, Edo State, 83-90

9. Bhardwaj, M. L. 2012. Effect of Climate Change on Vegetable Production in India in Vegetable Production under Changing Climate Scenario eds by Bhardwaj, M.L Shama, H.D, Kumar, M., Kumar, R., Kansal, S, Thakur, K, Singh, S.P, Kumar,D., Kumar, S., Gupta, M and Sharma, V. A. Gardening Guidebook from Centre for Advanced Faculty Training in Horticulture (Vegetables).

10. Hang, C. 1994. Vegetables for food security and health. In: Ritcher, J., Schnitzler, W.H., Gura, S. (Eds.). Vegetable Production in Periurban Areas in the Tropics and Subtropics -Food, Income and Quality of Life,
Proceedings of International Workshop, 14-17 November 1994, Zschortau, Germany, 49-63.

11. Sirmin, L., E.M Joann, L. I-Min and R.C. Stephen, H.H. Charles, C.W. Walter and E.B, Julie, 2000. Fruit and Vegetable intake and risk of Cardiovascular disease: the Women's Health Study1, 2. The American Journal of Clinical Nutrition. 72(4):922-928.

12. Ogunlesi, M.,W. Okiei, L. Azeez, V. Obakachi, M. Osunsanmi and G. Nkenchor 2010.Vitamin C Contents of Tropical Vegetables and Foods Determined by Voltammetric and Titrimetric Methods and Their Relevance to the Medicinal Uses of the Plants. International Journal of Electrochemical Science, (5):105-115.

13. Central Bank of Nigeria. 2006. Annual Report and Statement of Accounts, Abuja, Nigeria.

14. Adeniyi, A. 2017. Impact of climate variability on vegetable crops in Ilorin, Kwara State, Nigeria. Ruhuna Journal of Science. 8(1): 44-54.

15. Jayapiratha, V., M. Thushyanthy and S. Sivakumar, 2010. Performance Evaluation of Okra (Abelmoshus esculentus) under Drip Irrigation System. Asian Journal of Agricultural Research, 4(3): 139-147.

16. Akinbile, C.O and M.S.Yusoff, 2011. Growth, Yield and Water Use Pattern of Chilli Pepper under Different Irrigation Scheduling and Management. Asian Journal of Agricultural Research 5 (2): 154-163.

17. MOFA 2013. Okra Production. Horticulture Development Unit (HDU-DCS), MOFA Ministry of Food and Agriculture. Republic of Ghana.

18. HAIFA Group, 2017. Crop Guide: Growing Tomato. https://www.haifagroup.com/articles/crop-guide-growing

19. Putland, D and P. Deuter, 2011. The effects of High Temperatures on Vegetable Production and the Rapid Assessment of Climate Risk in Agriculture. In 2011 APEC Workshop on Collaboration on the Promotion of Indigenous Vegetables for Coping with Climate Change and Food Security. Asia-Pacific Economic Cooperation.

20. Kondinya, A.V.V., P. Sidhya and M.K. Pandit, 2014. Impact of Climate Change on Vegetable Cultivation - A Review. International Journal of Agriculture, Environment \& Biotechnology Citation: IJAEB. 7(1): 145-155.

21. Newton, A.C., S.N Johnson and P.J. Gregory, 2011. Implications of climate change for diseases, crop yields and food security. Euphytica, 179: 3-18.

22. Lovatt, J., G. Gullelove, R. Wright, N. Meurant and J.O. Barnes, 1998. Tomato Information Kit Department of Primary Industries, Bris bane.

23. Ernest, E. 2015. Heat Effects on Vegetable and Fruit Crops. Cooperative Extension College of Agriculture \& Natural Resources. University of Delaware.

24. De Koning, A.N.M. 1990. Long-term temperature integration of tomato growth and development under alternating temperature regimes. Scientia Horticulture Australia Limited, Sydney, Australia. 
25. Peet, M.M., D.H Willits and R. Gardner, 1997. Response of ovule development and post-pollen production processes in male-sterile tomatoes to chronic sub-acute high temperature stress. Journal of Experimental Botany, 48: 101-111.

26. Erickson, A. N and A.H. Markhart, 2012. Flower developmental stage and organ sensitivity of bell pepper (Capsicum annuum L.) to elevated temperature. Plant Cell and Environment. 25: 123-130.

27. Masariramb, M.T., Z. Dlamini, A. M. Manyatsi, P.K. Wahome, T.O. Oseni and V.D. Shongwe, 2012. Soil Water Requirements of Amaranth (Amaranthus hybridus) Grown in a Greenhouse in a Semi-Arid, SubTropical Environment. American-Eurasian Journal of Agriculture \& Environmental. Science. 12 (7): 932-936.

28. Directorate Plant Production, 2013. Amaranthus Production Guidelines. Department of Agriculture, Forestry and Fisheries. Republic of South Africa.

29. MOFA 2011 .Garden Eggs Production. Horticulture Development Unit (HDU-DCS), MOFA Ministry of Food and Agriculture. Republic of Ghana.

30. Aondoakaa, S.C. 2012. Effects Of Climate Change On Agricultural Productivity In The Federal Capital Territory (Fct), Abuja, Nigeria. Ethiopian Journal of Environmental Studies and Management (EJESM). 5(4): 559-566

31. Awotoye, O.O and O.J. Matthew, 2010. Effects of temporal changes in climate variables on crop production in tropical sub-humid South-western Nigeria. African Journal of Environmental Science and Technology. 4(8): 500-505.

32. Welbaum, G.E 2015. Vegetable production and practices. CABI.

33. La Pena, R.D and J. Hughes, 2000 Improving vegetable productivity in a variable and changing climate. ICRISAT 4: 1-22.

34. Mary, A.L and A. E. Majule, 2009. Impacts of climate change, variability and adaptation strategies on agriculture in semiarid of Tanzania: The case of Manyoni District in Singida Region, Tanzania. African Journal of Environmental Science Technology. 3(8): 206-218.

35. Martinez, M. M., M.T. Estan, E.G. Moyano, J.O. Abellan and F.B. Flores, 2010. The effectiveness of grafting to improve salt tolerance in tomato when an 'excluder'genotype is used as scion. Environmental and Experimental Botany. 63: 392-401.

36. Altieri, M.A., C.I. Nicholls, A. Henao, and M.A Lana, 2015. Agroecology and the design of climate changeresilient farming systems. Agronomy for Sustainable Development. 35: 869-890.

37. Ndamani, N. and T. Watannabe, 2015. Influences of Rainfall on Crop Production and Suggestions for Adaptation. International Journal of Agricultural Sciences. 5(1):367-374.

\begin{tabular}{|c|}
\hline Persian Abstract \\
\hline DOI: 10.5829/ijee.2019.10.02.12 \\
\hline 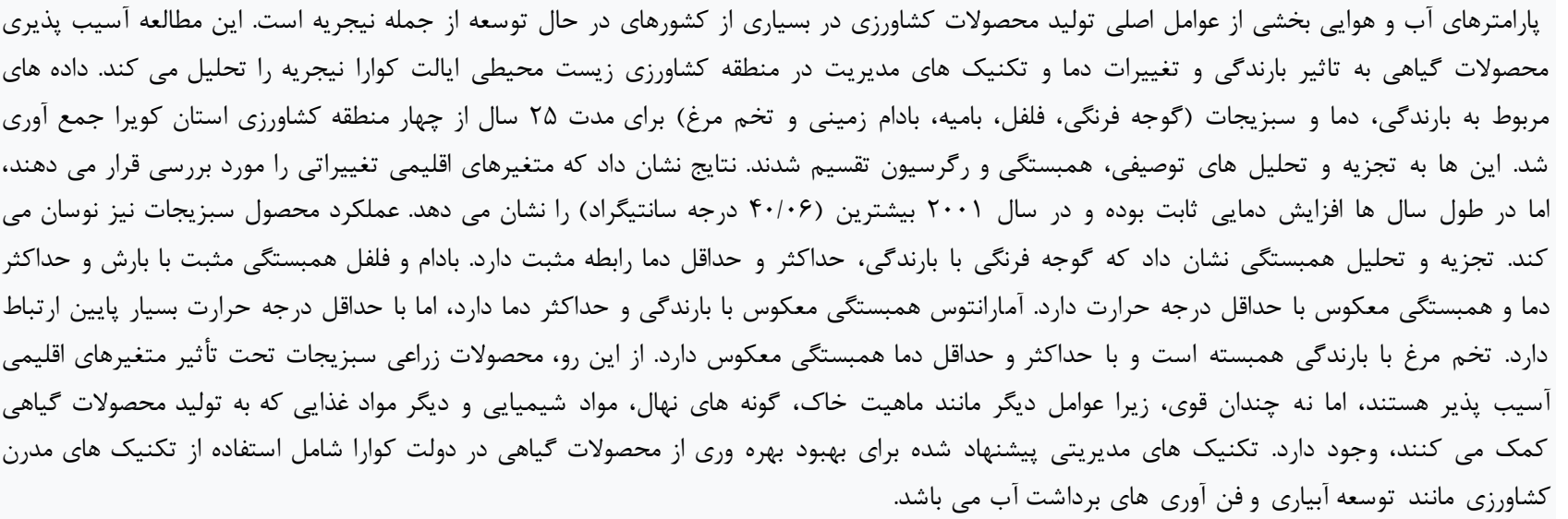 \\
\hline
\end{tabular}

